\title{
Decentralized Urban Governance and Water Supply Service Delivery in Ethiopia: The Case of Adama City
}

\author{
Ketema Wakjira Debela \\ Center for Federalism and Governance, College of Law and Governance Studies, Addis Ababa University, Addis Ababa, Ethiopia
}

Email address:

dwketema@yahoo.com

To cite this article:

Ketema Wakjira Debela. Decentralized Urban Governance and Water Supply Service Delivery in Ethiopia: The Case of Adama City. American Journal of Management Science and Engineering. Vol. 6, No. 3, 2021, pp. 63-76. doi: 10.11648/j.ajmse.20210603.12

Received: May 8, 2021; Accepted: July 5, 2021; Published: July 13, 2021

\begin{abstract}
Through devolving political powers, financial resources and administrative responsibilities to urban local government level, municipal decentralization in Ethiopia is largely intended to improve public service delivery. In this perspective, the aim of this study is to analyze whether the decentralization process has empowered the urban local governments to meet the demands for potable water supply services. The study relies on a case study design with particular reference to the city of Adama. It uses an extensive data collection, including key informant interviews, administrative and fiscal data. The analysis makes effective use of all these materials to investigate the effect of decentralization policy on water supply service delivery and local governance processes in Adama. The study found out that decentralized urban governance has been ineffective in the delivery of water supply service in Adama. This is because; firstly, the city lacks legal and institutional security. This makes it politically dependent upon the upper level regional state government. Secondly, contrary to the logic of 'Enterprise model' of water supply, the hierarchical political culture and the upward accountability of the Enterprise's Manager have reinforced the political control from above. Thirdly, the power to determine the structure, technical and financial sources of the city's water-supply project has been granted to regional water Bureau, while Adama water supply enterprise is practically required to provide water supply service to the residents. Fourthly, the decentralized urban water-service delivery is incompatible with the rapid and mostly informal pace of urbanization of Adama; and the city's horizontal physical expansion and demographic changes have already gone beyond the pressure zones for the water supply distribution system. Finally, the coordination and partnership among the multilevel water institutions -at federal, state and local governments- were mainly observed at times of water crises to moderate political and electoral contingencies. The implication is that for the urban local government to deliver effective water-supply service, this study contends, decentralization process needs to ensure adequate local capacity and effective coordination and partnership between the multilevel water institutions and stakeholders.
\end{abstract}

Keywords: Decentralization, Urban Governance, Urbanization, Federalism, Municipality, Adama, Oromia, Ethiopia

\section{Introduction}

Decentralization is a process by which authority, resources and functions are transferred from the center to other institutions at the subnational system, with decision-making largely vested with the people [1]. It entails the transfer of authority (decision-making and enforcement power) and responsibility for public functions from the central government to subordinate or quasi-independent government. There is increasing consensus that it is a necessary element for promoting good governance, combating poverty and delivering public services effectively. Theoretically, decentralization is expected to improve public service delivery at local level because it bestows political, administrative and financial capacities on public institutions at this level. Apart from their political and administrative capacities, local governments are envisaged as having financial autonomy that enables them to finance the functions assigned to them and execute their decisions and preferences [2]; conversely, the lack of adequate financial autonomy makes them dependent on supra-local governments and the implementation of higher-level government policy preferences [3]. As such, one of the aims of the decentralization agenda is to improve service delivery by local governments. The latter's ability to do so depends, however, on the adequacy of their financial and administrative 
capacities [4]. In order for decentralization to bring about effective local service delivery, transferring resources and fiscal competences and ensuring adequate local capacity are prerequisites for success.

Ethiopia officially launched the District Level Decentralization Program (DLDP) in 2001-2002. Among the DLDP's core objectives were institutionalizing viable development centers at local levels, enhancing democratization, promoting good governance, and improving service delivery [5] The program necessitated the implementation of wider-ranging activities at woreda level. The first factor that led to the adoption of decentralization at woreda level was the realization of the difficulty in managing the country's political, social and economic activities exclusively from the center. It has been evident that center and the regions neither possess the capacity nor the time to effectively deal with all the numerous issues surrounding service delivery, issues that could be better handled at the local level [6].

In spite of this, the delivery of local services has remained a challenge for local governments because, in the context of federal and/ or decentralization system, the water supply provision is beyond the local capacity. The provision of such service is a rallying point for several institutions and actors including state, non-state and the clients; as the water production and provision systems require synergized efforts among the different stakeholders having expertise, resource and jurisdiction. The existing studies on urban water supply service restrict their level of analysis to a local or municipal level which underemphasizes the role of multilevel institutional and stakeholder's involvement in the water service delivery system. The regional state and federal governments, however, echo the lack of good governance as s primary cause for the deficiencies in the water supply and delivery systems in the rapidly urbanizing cities of Ethiopia. Moreover, the same governmental actors predicate rapid rate of urbanization (particularly expressed in terms of population growth and urban expansion) as exerting unanticipated burden on the existing service deliveries.

The aim of this study is to analyze whether the decentralized urban governance process in Ethiopia has empowered the urban local governments to meet the demands for potable water supply services, with particular reference to the city of Adama. In so doing, the study relies on a case study design. This study focuses on the city of Adama, one of the fast growing cities of Ethiopia located at $100 \mathrm{~km}$ from the Capital, Addis Ababa. The city is at the intersection of the main highways coming from Dire Dawa, Harar, Bale and Arsi. A large number of trucks use this same route to travel to and from the seaports of Djibouti, where different imports to the country first arrive. Based on the past two censuses conducted in 1994 and 2007, and the city has a total population of 127,842 and 220,212 , respectively; which shows an increase of $72.25 \%$ over the period. In fact, as of today, the population of the city is expected to increase by far to these figures. Theoretically, Adama is the first grade city of Oromia with the most comprehensive master plan as developed in 2004, which has not been fully revised since then.

The study has used an extensive data collection, including elite interviews, administrative and fiscal data. Semi-structured interviews were held with residents of Adama, politicians, bureaucrats, and experts. Respondents of the interviews were selected through the snowball system to gather wide ranges of opinions and perspectives on the issues of rapid urbanization and urban water governance. Inasmuch as the study focuses on decentralized and institutions for urban water service delivery, the research participants are drawn from multilevel governments, including the Gandaas (lowest administrative units in the city), Administration of the city of Adama and from the Oromia National Regional State. At Gandaas level, key informants from the four urban water supply enterprises in the city of Adama were consulted. At city level, key respondents included: Municipal manager, members of city council, head and expertise from water supply service Enterprise, revenue office, and expertise from urban land development and management. At regional state level, the key respondents were drawn from pertinent bureaus ranging from urban land development and management Agency, Urban planning institute, and Water, Mines and Energy Resource Development. The analysis makes effective use of all these materials to provide a clear picture of decentralization policy effects on urban water service delivery and local governance processes and the forces that influence them. The analysis follows two lines of investigation: the first examines whether the city has adequate local capacity to meet urban water-service demands; and the second examines institutional cooperation and coordination functions in urban water-service delivery.

This article contains five sections. After the introduction, the second section sets out a theoretical framework for evaluating how the various dimensions of decentralization impact on local government service delivery. The third section briefly describes decentralization processes and the place of urban local government in the federal system of Ethiopia. The fourth section begins with description of the organizational structure of Adama water supply service Enterprise. It then analyzes to what extent decentralization and multilevel institutional coordination enable Adama to effectively deliver water-supply services. The final section provides concluding remarks.

\section{Conceptual and Theoretical Frameworks}

\subsection{Decentralization and Service Delivery}

Decentralization can be understood in terms of three dimensions: political, administrative and fiscal. To begin with the political dimension, the assessment of the degree of decentralization involves determining whether the authorities are appointed by the regional and/or central government, or elected by local residents and appointed by local councils. It also involves consideration of whether locally elected politicians' decision-making is democratic and inclusive [7]. 
Administrative decentralization, on the hand other, aims at transferring decision-making authority, resources and responsibilities for the delivery of public services from the central or regional government to local levels of governments. Assessing this dimension of decentralization involves ascertaining whether local governments meet service delivery obligations such as water supply. Decentralization can improve the delivery of public services if it develops the capacity of the relevant local institutions and creates an enabling environment for participation by non-governmental organizations (NGOs) and the private sector [8].

In turn, fiscal decentralization entails transferring power to local authorities to make autonomous decisions about revenue-collection strategies and expenditure decisions. The fiscal aspect of decentralization is meant to make local governments responsible for managing their own budgets, generating their own revenue, and generating full financial accounts. Indeed, decentralized local autonomy is unthinkable without commensurate financial autonomy, because it is local financial autonomy that determines the capability of local governments to obtain their financial resources through their own means and without recourse to, or dependency on, other governments that either at the same or higher level as they are.

Other scholar also maintains that a local government's financial autonomy resides in its freedom to impose local taxation, raise revenue within its assigned sources, allocate its financial and material resources, and determine and authorize its annual budget without external interference. Fiscal decentralization has become imperative for local governments as the basis for making independent decisions about the provision of public services [9]. It grants them discretion over revenue-raising, confers responsibility for expenditure and revenue, and involves a system of intergovernmental transfers and borrowing [10]. Financial autonomy and the extent of fiscal decentralization can be measured in terms of three further dimensions: revenue-raising power; spending responsibilities; and budgetary discretion.

The first dimension, revenue-generating power, pertains to the right and the ability to determine funding sources and the amount of financial resources. It involves the freedom to decide on local tax and fee rates as well as on the way the revenues are utilized [11]. The amount of internal resources at the disposal of local governments is essential for financing at least their mandatory expenditures [12]. The own-revenue-raising power available to local governments is thus of especial importance [13]. Where local governments cover a large portion of their budgets from internal revenue sources, this enables them to make more efficient and independent spending decisions [14]. With regard to the allocation external revenue from intergovernmental transfers, the local government's revenue autonomy can be assessed by examining the participation of local units in the shared financial institutions that decide upon revenue-sharing formulae as well as the utilization of transferred resources [15]. The second dimension of financial autonomy - expenditure power - relates to the right and the capability of local governments to determine the nature and magnitude of overall local public expenditure. Yilmaz et al. [16] make A similar argument is that a local government's expenditure responsibilities are an indicator of the extent to which it is capable of responding to local needs. The third dimension of financial autonomy is local government's budgetary discretion to balance revenue against expenditure needs by way of preparing and approving a budget.

Normatively, decentralization is expected to improve service delivery inasmuch as it bestows administrative and financial capacities and decision-making powers on lower-level public institutions. Whether decentralization considered in terms of its political, administrative and financial dimensions - has put local governments in a position to render optimal public services like water worth researching.

\subsection{Water Governance Models}

Global Water Partnership (GWP) proposes two principles for effective water governance: governance approach that needs to be transparent, inclusive, equitable, coherent and integrative; and the performance that needs to be accountable, efficient, responsive and sustainable [17].

Three different models of water governance models are evident in the literature [18, 19]. Heller [20], for example, identifies three models of urban water governance. The first is the authoritarian model that barely involves the local/municipal government and local community in the provision of water supply services. In this model, the local/municipality has a weak control and participation in water services. The second is the local autonomy model that explicitly recognizes the participation of local community and downward accountability of the municipal authority to the public. The third is an integrated model that contains the shared management of water supply services by the state, local/ municipality and community. This model boldly recognizes "the complex set of interdependent relationships" for water supply services [21], and the participation of all relevant stakeholders ranging from state, civil society to the market. According to the integrated model, water supply service delivery cannot be met by a single level of government and decentralization cannot be a panacea for the provision of urban water supply services. Rather, urban water supply service a subject of both adequate decentralization and multilevel institutional cooperation and partnership.

This third model, which is increasingly represented as integrated Water Resource management approach (IWRM), advocates that the management of water from economic, social and environmental perspectives, and the participation of user communities [22]. Rees puts the IWRM as an explicit recognition to "the complex set of interdependent relationships" for urban water supply services. In this perspective, the concept of water governance has shifted from bureaucratic hierarchies to governance networks [23]. IWRM considers all water services, sources, stakeholders, and impacts in order to create the best possible outcome in the urban water management. Rees argues that this approach is about the creation of institutional framework within which water relevant roles and functions are to be performed at 
appropriate scales.

Therefore, under the IWRM approach, decentralization is not the panacea for the provision of water supply services. On the one hand, as Rees puts, the decentralized urban water management presumes demand oriented provision, greater accountability and technical flexibility. On the other hand, for the decentralized urban water services to operate there is a need for strong strategic and regulatory framework and institutions that promote cooperation and coordination. Accordingly, urban water governance involves duties and responsibilities that transcend jurisdictional boundaries of the urban local governments and coordination of the functional boundaries of water utilities.

\section{Decentralization and Institutional Contexts for Urban Water Supply Service in Ethiopia}

\subsection{Urban Local Governments in the Decentralization Processes of Ethiopia}

Local governments in general, and urban local governments in particular, are not among the federating units of nations, nationalities and peoples that comprise the federation of Ethiopia. Nonetheless, the Constitution implicitly envisages two ways of establishing local units. On the one hand, local governments can be established for the purpose of ethnic self-rule [24]. On the other hand, local government can be set up for the sake of administrative convenience and public participation [25]. Although the federal government can set regulatory standards that influence local governments through the formulation of general policies on national, social and economic matters [26] as well as through the enactment of proclamations such as that on urban land lease [27], urban governments have been the operational competence of regional governments. They (urban governments) are the creations of ordinary statutes, not of regional constitutions [28]. However, the regional governments cannot simply form local governments as lower administrative units lacking democratic elements but have the duty to establish such governments on the basis of democratic principles [29].

Under the first phase of decentralization, which lasted from 1991 to 2001 , there was little attention given to the "urban agenda" in Ethiopia as the ruling party's primary focus was on 'rural agenda' through the policy of Agricultural Development Led to Industrialization (ADLI). By then, the overwhelming revenue amounting to $54 \%$ of GDP was from rural areas [30], and much of the political constituencies came from the same [31], and the development discourse of the period had subjected the urban biased development policy as a reason for rural poverty in Ethiopia as suggested elsewhere for emerging economies also. The relative lack of emphasis on urban issues in the early decade of the Ethiopian People's Revolutionary Democratic Front (EPRDF) regime could also be seen as a reflection of the lack of allegiance of the ethno nationalists to the 'city', and EPRDF's claim to the rural root.
Hence, the urban questions and policies to address urban problems were relegated under the guise of rectifying the hitherto urban biased policy. During this decade, a number of institutional constraints related to financial and political powers have challenged the urban local governments. Particularly, the own revenue sources could not cover the expenditure responsibilities and that made them dependent on upper level governments.

The second phase of decentralization, which was embarked upon in 2002, shows that the original intent of municipal decentralization was to mobilize own revenue sources and strengthen the capacity for addressing the needs of cities and towns. This was part of an emphasis on harnessing and prioritizing regional resources for rural development [32]. To this end, the regional constitutions were revised to decentralize and grant some political, administrative and financial powers to district or municipal governments in conformity with the national Sustainable Development and Poverty Reduction Program. In the process, urban administrations have been given the opportunity to prepare and implement their development plans. Many studies [33, 34] show that urban governance still struggles with the dual accountability of serving the interests of the electorate, on the one hand, and meeting the requirements of upper-level governments, on the other. Furthermore, most of the decisions on legal status and planning are made by the ruling party at regional-state level and higher and passed down to the urban centers.

Nonetheless, it was only in 2005 that the government came up with the urban development policy (UDP), after the problems of spontaneous and rapid urbanization reached its climax. The policy was formulated to address the socio-economic problems of the Ethiopian urban centers by fostering rapid and sustainable development and ensuring democracy and good governance [35]. The policy was considered as the recognition for the potential contribution of urban centers to the national economy, reaching up to $66 \%$ of GDP [36]. The urban development packages like small-scale enterprise schemes and the integrated housing developments had been applied by the EPRDF to win back the support of the urban residents particularly the youth, which the ruling party lost to the opposition parties in 2005.

Rural or Woreda administration is constitutionally recognized in the regional or sub-national constitutions. In Oromia regional state, where the case study-Adama is found, Oromia Regional State constitution of 2001 does not explicitly express the status of urban localities. Cities or urban administrations are not among the levels of government created by the regional state constitution. In the period prior to 2002, urban local administrations were subsumed under District (Woreda) and Zonal Administrations. This was, however, changed in the period after 2001/2 with the launching of second wave decentralization for the implementation of development policy. A number of city proclamations were issued by the regional state councils and the Caffee created the city administrations through city proclamations. 
Under Proclamation № 26/1999, for example, the city of Adama was designated as 'Special Zone.' This status made Adama directly accountable to the Oromia region, and there was no other administrative structure between the city and the region. In 2003, the designation of Adama as town was abandoned by the Proclamation № 65/2003. This Proclamation sets the Council-Mayor model of municipal governance for Adama [37]. Accordingly, the Mayor should be elected by the City Council from among its members, and the Mayor is accountable to the City Council and the President of the Oromia region. This was later amended by Proclamation № 116/2006 and the Mayor's accountability to the city council was abrogated, and the appointment and accountability of the Mayor of Adama has been granted to the President of the regional state of Oromia [38]. No doubt, the appointment and upward accountability of the Mayor hinders local democracy as the selection of the Mayor is not anchored in the local electorates.

According to the Council-Mayor theory of municipal governance, the Mayor is expected to be not only a politician but also he/she must be a competent in public management [ 39 , 40]. The practice in Adama [41], however, shows that the Mayor has been in office primarily because of the loyalty to the ruling party and regional executive. Neither urban governance related experience nor relevance of their profession attracted considerable attention in the appointment of Mayors. Also, the model has resulted in neither strong mayor nor strong council. Moreover, the appointment and accountability mechanisms do not allow for stronger level of institutionalization, as the key positions like the Mayor are unstable and the institutional memories are perturbed by the time this individual vacates from the position. This is practically observed in the case of Adama because there has been change of Mayors short of the tenurial five years' period of the City Councilors (one mayor has averagely served for about six months since 2009).

\subsection{Urban Water Policy and Institutional Frameworks of Ethiopia}

The Federal Constitution gives the federal government the power to formulate water policies and regional states the power to administer natural resources in accordance with federal laws [42]. Accordingly, the federal government formulated the Water Resources Management Policy (WRMP) in 1999 and thereafter enacted Water Resources Management Proclamation No. $197 / 2000$ and Regulation No. 115/2005 to implement it. The Proclamation underscores that all the water resources of the country are the common property of the Ethiopian people and state. To this effect, the policies-cum-legal frameworks have established institutions that play regulatory, supportive and overseeing roles and institutions that are directly involved in implementation.

The overall objective of WRMP is to enhance the well-being and economic productivity of the Ethiopian people through the provision of adequate, reliable and clean water supply and sanitation services [43]. The major principles of the WRMP (1999) and the Water Sector Strategy (2001) are:
1) to develop ownership by lower tiers of government and enhance the management autonomy of the lowest possible levels;

2) to promote the involvement of all stakeholders;

3) to work towards full cost recovery by the urban water-supply system so as to ensure that all water-supply undertakings adequately address costs associated with maintenance and operation and are based on cost-recovery principles; and

4) to enhance urban water-supply through autonomous bodies, that is, enterprises.

According to the Water and Sanitation Policy (2011), the WRMP is underpinned by two priority actions: first, implementing a "full cost recovery" policy by strengthening the capacity and financial autonomy of urban water enterprises; and, secondly, increasing the focus on water resource sustainability by encouraging demand-management approaches and reduction in unaccounted water usage. Under the policy and legal frameworks, the Urban Water Supply Service Enterprise (UWSSE) is meant to perform its functions autonomously with very limited supervision and support from the regional and federal governments. The UWSSE has also been given the duty of covering all its service delivery charges by collecting water tariffs from its customers, given that the implementation of the water policy in urban areas hinges on fair tariff ratings, the willingness of clientele to pay for services, and efficient management of resources.

In terms of the WRMP and Water Sector Strategy, the Ministry of Water and Energy (MoWE) is responsible for formulating policies, strategies and action plans. It establishes national standards on quality, water infrastructure and related matters; and responsible for supervising the implementation of water policy; and provides technical support for Regional Water Bureaus [44]. As such, the Ministry has developed strategies as well as national guidelines on water supply and sewerage services. The Ministry is also in charge of channeling donor funds in the sector to local government entities.

\section{Assessing the Water Supply Service Delivery in Adama}

\subsection{Organizational Structure of Adama Water Supply Service Enterprise}

Whilst policy and programme formulation is the major responsibility of the federal ministry, the councils of the regional and sub-regional governments have the mandate to formulate economic and social development policies without prejudice to provisions of the Federal Constitution; and regional states have adopted the federal policy on water there is no separate regional water policy as such" [45].

The regions have been enacting proclamations, regulations and directives with regard to the urban water supply services. At regional level, Bureau of Water and Energy Resources (BoWER) is an executive organ responsible for the implementation of federal policies, strategies and action plans 
through adapting them to the specific conditions of the region. In addition, Water Bureaus exercise regulatory duties delegated to it by the Ministry. The duties of the BoWER include: (1) to build the capacity of the lower water offices and enterprises, (2) to contract out to private sector, set water tariffs, construction of water schemes (spring developments, small and large gravity schemes, motorized schemes, boreholes and shallow wells), (3) to carry out regulatory duties delegated by the of Ministry Water and Energy, and (4) to study, design, supervise and regulate water projects and exercise regulatory duties delegated by the Ministry. The BoWER has the responsibility for ensuring the provision of water supply services and to cooperate with the city and woredas administrations.

In Oromia National Regional State (ONRS), the regional Council (Caffee) has enacted the Proclamation No 78/2004 for establishment of Urban Water Supply and Sanitation Enterprise (herein after the Enterprise). This Proclamation along with the Amendment Proclamation No 97/2005 provides for the organizational structure, duties and power of the key organs of the Enterprise, accountability relationships between the Enterprise, Water Management Board (WMB) and the Regional Water Bureau, and financial mechanisms for the Enterprise. WMB is the supreme body of the Enterprise that follows and monitors the overall work of the enterprise [46]. It has the power to examine and approve the annual work program and budget of the enterprise, evaluate the financial and performance reports of the enterprise, determine the structure and salary of the staff of the Enterprise, select and assign the manager of the Enterprise, and can study and amend the rates of charges for the services that the Enterprise provides [47].

Under Article 7 of the Proclamation 78/2004, the Board functions as organization of several stakeholders at the city level. The Proclamation specifies the number, role and sectors from which the members of the WMB could be drawn. Accordingly, the Mayor of the city is the Chairperson whereas the Manager of the Enterprise serves as Secretary with non-voting participation in the Board. This arrangement has facilitated for the City Mayor to establish the Board as deemed necessary. The other members of WMB include: one person from Water Resource Bureau, one person from Health Office, one person from Women's Affairs Office, one person from Finance and Economic Development of the city, one person from Branch Office of Electric Power Corporation in the city, one person from Education Office, and two persons from customers of the Water Supply Enterprise.

Later, an Amendment Proclamation No 97/2005 to the Proclamation 78/2004 has shifted the power of establishing the WMB from the Mayor to the Bureau of Water and Energy Development (BoWERD). Nowadays, it is the BoWERD which establishes the WMB for $1^{\text {st }}$ and $2^{\text {nd }}$ grade cities of the region, and assigning the Chairperson of the $\mathrm{WMB}$ is the mandate of the Bureau [48]. The composition of the members of the Board remains the same. Adama being the first grade city of Oromia, the WMB of Adama City Water Supply Services Enterprise (ACWSSE) is accountable to BoWERD.
The ACWSSE is accountable to the Board established by the Bureau. The Bureau in turn is accountable to the Regional Cabinet which in turn is accountable to the Regional Council or the Caffee. Thus, the legal and institutional framework for the water service delivery in Oromia has set up long and upward accountability mechanisms.

The Key informant [49] from ACWSSE notes that the selection of the members of the WMB helps the political and the party interference from both the city and regional actors. For example, the Chairperson of the Adama WMB, $\mathrm{Mr}$ Alemayehu Tegenu, was also the Federal Minister of Water and Energy. This shows that the key decision makers in the Board are also key politicians at the supra-local levels. The Manager of the ACWSSE is appointed by the Board and is accountable to the same [50]. He or she has the duty to implement the decision of the board; and can employ, manage, and terminate the employment of the workers of the Enterprise and perform other duties as assigned to him/her by the board [51]. In principle, the Manager of the Enterprise is expected to be appointed based on relevant water related education and work experience. The appointment in the case of Adama City Water Supply Enterprise, however, shows that the selection of the Manager has been based on political membership and affiliation to OPDO/EPRDF and/ or personnel networking within the assigning committee, thus undermining the technical and professional competences. Given the Manager is selected based on the political affiliation than water related skills, the Manager focuses on addressing the political issues and interests of those who appointed him/her. Hence, the Manager's role is to "maintain power relationships with the key decision-makers in the city and in regional level." Also, the lack of regular meetings of the Board delays the actions of the manger on matters that require the decisions of the Board. Inasmuch as the Manager is inclined to please politicians, it has become difficult to separate the political from the managerial activities. This condition has obscured the checks and balances between the regulator and the service provider.

\subsection{Water Supply Service Versus Demand in Adama}

The pipe water service for Adama had begun during the Italian period. The Italians had dug two deep wells at Malka Hida on the bank of Awash River, $11 \mathrm{~km}$ to the South East of the City towards the Wanji Sugar factory. The Italians helped to provide piped water from this river and the municipal office of Adama was also created by the Italians $[52,53]$. Initially, when the first protected water source was founded for Adama, the number of customers were 8185 . However, in the middle of 1970 s, the population of Adama exceeded 100, 000. Ten boreholes at Melka Hida ground water field were sources of fresh drinking water for the city until it was shifted to surface water source constructed on Awash in 2002 [54]. Beyond the incapacity to meet the rising water demands, the inability to meet the demand, the water supply from Malka Hida boreholes were abandoned due to the problem of high fluoride concentration which varied from 2 to $8 \mathrm{mg} / \mathrm{l}$ and the concentration of fluoride in the distribution system was about $5 \mathrm{mg} / \mathrm{l}$. This fluoride content is beyond the WHO standard 
$(1.5 \mathrm{mg} / \mathrm{liter})$ and it had seriously damaged the health (bone and teeth) of the consumers [55].

At present, the principal source of drinking water supply for the city of Adama is River Awash which is located west of the City of Adama, about $16 \mathrm{~km}$ from the central office. Besides, some of the old boreholes within the city have been made active to supplement the existing water supply from Awash treatment plant. The average output ranges from $19000 \mathrm{~m}^{3}$ to $20,000 \mathrm{~m}^{3}$ per day while the demand ranges from $35,000 \mathrm{~m}^{3}$ to $36,000 \mathrm{~m}^{3}$ per day. The city is the second largest in terms of the number of water customers, next only to Addis Ababa.

Table 1. Customers of Adama Water Supply Services from 2011 to 2015.

\begin{tabular}{|c|c|c|c|c|c|c|}
\hline \multirow{2}{*}{ Types of Connections } & \multicolumn{6}{|c|}{ Fiscal Years } \\
\hline & 2010 & 2011 & 2012 & 2013 & 2014 & 2015 \\
\hline Private domestic & 26,794 & 29,651 & 31,203 & 38,400 & 39,120 & 43,819 \\
\hline Commercial Industrial & 654 & 847 & 697 & N/A & N/A & 740 \\
\hline Government Institutions & 1675 & 1570 & 1761 & 1761 & N/A & 1325 \\
\hline Public Fountains & 146 & 152 & 190 & 187 & 198 & 202 \\
\hline Total water connections & 29,276 & 32,220 & 33,851 & 36,543 & 39321 & 46,086 \\
\hline
\end{tabular}

(Source: Adama City Water Supply Service Enterprise, 2016)

As Table 1 above illustrates, the Enterprise states that the customers of the water supply are more than 46,000 with about 45 liter/day/capita. The water supply system was designed to process and deliver drinking water at the flow rate of $330 \mathrm{l} / \mathrm{s}$. But the actual rate ranges from $250 \mathrm{l} / \mathrm{s}$ to up to 280 $1 / \mathrm{s}$ while the demand as of the 2016 is $5501 / \mathrm{s}$ [56]. But the BoWERD standard for water supply for the city of Adama is 80 Littre/ capita/ day. The Enterprise [57] estimates that the total population of the city and its surrounding for which it has to provide water service is 440,000 . The Projected population of Adama alone is 356,000 . If we take the daily production to be $20,000 \mathrm{~m}^{3}$ and compute the coverage of water supply for Adama city, the estimate of water coverage is $56.18 \%$ i.e. nearly half of the population could not access water. However, coverage figures are inflated to $74 \%$. Table 2 below clearly shows the gap in the water demand and actual water delivered in the city.

Table 2. Adama City Water Production, Demand and Supply from 2011 to 2015.

\begin{tabular}{llllllll}
\hline \multirow{2}{*}{ Description } & Unit & \multicolumn{2}{l}{ Fiscal Years } & & & & \\
\cline { 2 - 7 } & & $\mathbf{2 0 1 0}$ & $\mathbf{2 0 1 1}$ & $\mathbf{2 0 1 2}$ & $\mathbf{2 0 1 3}$ & $\mathbf{2 0 1 4}$ & $\mathbf{2 0 1 5}$ \\
\hline Water supplied & $\mathrm{M}^{3}$ & 3.3 & 4.9 & 5.5 & 5.87 & 6.4 & 7.1 \\
Water demanded & $\mathrm{M}^{3}$ & 4.8 & 9.13 & 10.95 & 12.41 & 12.75 & 13.14 \\
Leakage & $\%$ & 25 & 40 & 35 & 35 & 21 & 20 \\
coverage & $\%$ & 74 & 90 & 80 & 73 & 70 & 70 \\
Length of water lines & $\mathrm{km}$ & 200 & 235.3 & 348.03 & 360.38 & 366.5 & 390 \\
\hline
\end{tabular}

(Source: Adama City Socio-Economic Profile of the City 2016)

\subsection{Adama Water Enterprise Capacity: Structure, Staffing and Finance}

As Mr Tagay, the Head of the Human Resources Management and Logistics puts, the ACWSSE has no severe human capacity problems. He notes that the existing human resource is enough for the organizational structure developed by the BoWME. Most of the workers are qualified, and some are even more than qualified as to the needs of the organization. Hence, pursuant to the structure set by the Bureau, the bureaucracy is occupied by professional personnel. An expert [58] in the ACWSSE, however, stresses that there has been a problem of placing the right person at the right place. For example, positions of planning and budget are not occupied by the economists. Besides, although the structural set up of the Enterprise requires electrical and mechanical engineers, there are no qualified staffs in this regard. It also lacks adequate incentives to hold the highly skilled personnel. The Enterprise pays ETB 7168 for an engineer, and this is found to be unattractive for an Engineer [59].

Table 3. Educational Level of the Staffs of Adama Water Enterprise.

\begin{tabular}{ll}
\hline Qualification & No of staff \\
\hline Above first Degree & 3 \\
First Degree & 52 \\
Diploma & 6 \\
Certificate & 3 \\
Level 1 to 4 & 117 \\
Others & 53 \\
Total & 234 \\
\hline
\end{tabular}

(Source: Human Resource Unit, ACWSSE December 2016)

\section{Financial Capacity}

Primarily, the source of finance for the UWSSE is the enterprise itself. The Enterprise should administer itself by its own fund [60]. Accordingly, the source of fund for the enterprise [61] includes: water sales and charges, loan, donation and grant both in cash and in kind assigned by the administration of the town and other sources of fund.

Also, "the regional government may grant necessary support for the establishment and expansion of water supply 
services by assessing their capacity." In this line, funds for Adama -Mojo Project fund come from loan, regional

government grant, city administration donation and the Enterprise's contribution.

Table 4. Adama City Water Enterprise Revenue and Expenditure Performance from 2009 to 2015.

\begin{tabular}{|c|c|c|c|c|}
\hline Fiscal year & Total Revenue & Direct Production Costs & Total Expense (the general administrative overhead cost) & Net income \\
\hline 2009 & $23,440,422.00$ & $8,091,235.00$ & $9,665,830.00$ & $5,683,357$ \\
\hline 2010 & $38,312,340.00$ & $9,686,543.00$ & $8,103,514.00$ & $20,522,283$ \\
\hline 2011 & $37,778,356.00$ & $11,413,494.00$ & $12,420,841.00$ & $13,944,021$ \\
\hline 2012 & $45,967,423.43$ & $16,967,846.43$ & $12,647,225.44$ & $21,919,774.92$ \\
\hline 2013 & $52,921,351.53$ & $13,881,958.41$ & $21,269,736.92$ & $14,674,768.18$ \\
\hline 2014 & $62,622,056.64$ & $19,492,095.87$ & $17,222,263.54$ & $25,907,697.24$ \\
\hline 2015 & $57,306,357.06$ & $15,832,918.08$ & $26,874,875.73$ & $14,598,563.25$ \\
\hline
\end{tabular}

(Source: ACWSSE Finance Administration Unit, August 2017)

The revenue of the Enterprise has been increasing from year to year. The net income of the Enterprise, however, has not been increasing. This is because the direct cost of production and the general administrative costs were steadily increasing. Over the last seven years, the Enterprise has averagely raised ETB45, 478329.5229 as revenue and the average expense during the same period was ETB29, 081482.4886. It is however important to note that there is no financial capacity for the Enterprise to respond to the increasing water demands by expanding the water resources and infrastructures.

As part of the water supply service expansion in the city of Adama, the contribution of the regional government has been about ETB100, 897, 579.81 million each year over the last five years. Hence, the Enterprise mostly depends on other sources of funds rather than on its own revenues [62]. The cost recovery principle has so far made the enterprise self-sufficient for recurrent and smaller maintenance and operation activities.

Apart from the structural, human resource and financial factors, the political context in which service provider and users operate influences water supply system. In this case, the members of the key decision making body-the Board- and core process owners have been the political actors. The political class was hardly critical about the service provision capacity of the staff. One seldom witnesses the imposition of sanctions for inappropriate service and rewards for efficient performance. On the other hand, the key informant [63] understands the relationship between water users and the government as follows: if the government cannot solve the problem of water availability in Adama city, we should not let it to govern us.

The lack of clear separation between the policy makers and service providers, as both are politically networked, has affected the ability of policy makers to hold providers accountable. Autonomy for the Board is not possible. Furthermore, users should also know how factors such as capacity, federal and regional government legislation and directives, government restrictions on autonomous decision making limit the ability of the providers to meet users demand. Although the Oromia Regional Bureau of Water has the power to determine the form and structure the Enterprise, fund the expansion of water supply services and employ its professional Expertise solely to enable the Enterprise, the reality is that Enterprise lacks autonomy in terms of institutional, structural and financial factors.

It has been widely noted that fiscal decentralization could allow local governments to charge for water services, which in turn can enhance the local policy makers' accountability to citizens. On the opposite case, without access to enough revenues from the clients, the service provider depends on the policymakers for fiscal resources to maintain service provision and in this way the local accountability may be harmed.

\subsection{Water Supply Service and Urbanization of Adama}

According to the information from ACWSSE, a total of 35,000 visitors come to Adama each day from four directions, and about 5000 people spend their night in the city. Beyond the residents of the city, Adama has been a destination or transit a number of daily visitors in the form of passengers, tourists, conference participants and others who are usually in the rise. Above all university and colleges students and their tutors, and many incomers from the surrounding areas add up to the number of usual residents which give rise to above 400,000 people [64].

As the head of the technical design unit of ACWSSE puts, the water supply from Awash was designed for 25 years. There were 160,912 persons when the project was constructed and the Adama city population forecast was estimated at 287,169 . At the time of inauguration only $50 \%$ the water produced was demanded. The water supply from Koka had satisfied the water demands of the population for five consecutive years. Thereafter, the water project, which was meant for 20 years, could not meet the demand of the population even for half of the design period. Instead, the demand has increased by $30 \%$ in a decade, and the water produced by the Awash Treatment Plant could not meet the demand. 


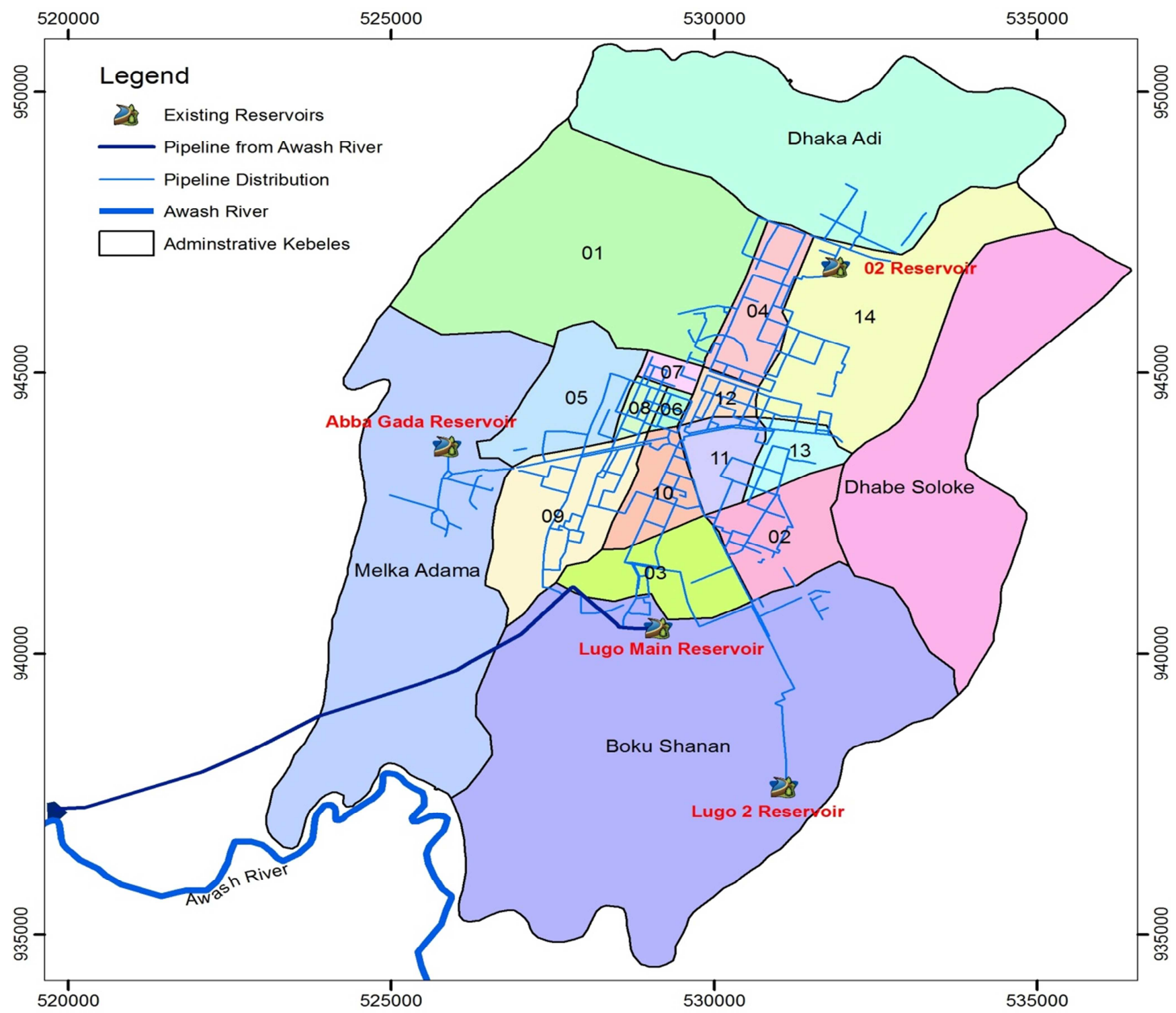

(Source: Sketched by Researcher based on the Data from Adama Water Supply Enterprise, 2017)

Figure 1. Adama City Existing Water Pipeline Distribution System.

As the Figure 1 above shows, the peripheral built up areas of the town are beyond the reach of pipelines. Water customers go far off distances in search of water and carry it along and also spend much time even in queuing up near the water taps.

Moreover, the expected distributional length of the water supply network in the city is $1000 \mathrm{~km}$ but the actual length of the distributional line is $2016473 \mathrm{~km}$, as of 2016 . Even Worse, the existing distributional line did not appropriately work. The senior hydraulics Engineer [65] underscores that part of the water distributional problem is due to the problem of design in the pressure zones of the water supply system. The Pressure Zones were not separately studied and water couldn't flow as expected. Furthermore, prior to the establishment of the Awash treatment plant, the average percentage of leakage was $37 \%$ but now averagely $25 \%$ of the water produced has been lost because of leakage problem [65].

\subsection{Ecological Factors of the Awash Catchment}

Ecological factors- nature of water source in the catchment, soil character and flooding- of the Awash catchment area have been constraining the water supply services to Adama city. The highly degraded nature of the Awash catchment (Akaki catchment, Mojo Adama catchment and Adama Wanji catchment) and the water characteristics of the area have reduced the capacity of the system. The Awash catchment is highly degraded. Silt concentration is high and detection take longer time than expected hampering the production of water. The catchment transports alluvial deposits easily. Hence, the soil of Adama catchment has been subjected to flooding. Flooding has exposed the water pipes to the external damages. The surface water of Awash contains up to $40 \%$ iron, and this has caused rusting of water pipes [66]. 


\subsection{Institutional Coordination and Stakeholders Involvement in Adama Water Supply Service}

Under the water policy and institutional frameworks of Ethiopia, water service provision is not restricted to one level of government or institution. Rather multiple actors and institutions are involved in the water service provisioning. In this perspective, the subsequent sections; first, discusses the nature of relations between the water enterprise of the city and regional water bureau. It then examines the relation between the Adama city water enterprise and the urban land planning and municipality of Adama city Administration. It finally analyzes how the institutional coordination works between Adama city water enterprise and the related service sectors.

\subsubsection{Vertical Relation Between the Water Bureau and the Enterprise}

The Bureau of Water and Energy Resources Development of Oromia (BoWERD) has been given the key regulatory powers over the urban water supply services. The Bureau has the power [67] to: 1) follow up that the services provided by the Enterprise is in accordance with the federal Water Resource Management Policy and laws of Ethiopia; 2) create favorable conditions that enable the enterprise to get the necessary support from the government and NGOs in the form of loans, grants and gifts; 3) finalize the water tariff recommended by the Enterprise as a whole, amend or reject, or implement the rectified tariff; and 4) to issue necessary directives [68].

The Bureau is also involved in the urban water governance in the sense that the enactment of the amendment Proclamation № 97/2005 grants the power to choose the Chairman of the urban water management Board to the Bureau. Moreover, Water project is one of the areas that demand coordination of jurisdiction, expertise and resources. In this perspective, the BoWERD has the mandate of building capacity, support and approve funds for the water projects; and the Bureau is supposed to take the lead in planning, monitoring and evaluation of urban water supply projects. The Bureau approves water projects funds, while the Enterprise works as source of information, facilitation and participation in the water projects. Thus, the regional BoWERD has been granted the responsibility to do overall regional water resources planning and designing of water projects which are beyond the capabilities of the local units [69].

In terms of mandate, the urban water enterprise has no power to enforce contractors of water projects. This has made the enterprise unable to resolve the problem of design and the implementation because the contract agreement on water project is the mandate of the Bureau. The informant [70] has, for example, underlined that a water reservoir was constructed at Ganda Haara (Bole) of the Adama city for about ETB 7.3 million. The enterprise has not approved the completion of this Reservoir because the reservoir could not hold water. The same informants have underscored that the water project fails because of the failure of the follow up of the technical specification and inadequate human resource on the part of the consultant (private or public).
Urban water supply projects were seen as tool for political support and gaining vote banks. Two conditions that have attracted the attention of city and regional leaders alike: water crises and periods of election campaign. Both of these conditions were derived by the need for maintaining political support which all the key decision makers at all levels want to retain. Demonstratively, the water supply projects have been either launched or inaugurated during election campaign. The support from Bureau, therefore, came as firefighting strategy at times of water crises and at moments when urban water problems reach political flashpoints. For example, to resolve the acute problem of water shortage in Adama city in 2015, this was the year for the fourth national election in the political landscape of Ethiopia, the Enterprise, Adama city Administration and BoWERD had shown collaboaration. In the fiscal year 2014/15, the Koka Water Project expansion was launched with total outlay of ETB 302,739,973.23. The Enterprise, Adama city Administration and BoWERD contributions accounted for $25 \%, 25 \%$ and $50 \%$, respectively [71]. Similarly, the Adama Mojo water project also brought the collaboration between the Bureau, the City and the Enterprise. To this end, ETB 905million is the loan from African Development Bank, ETB 79.9million from the Regional state of Oromia, ETB 55.8million is from Adama City Administration and ETB 23.96 million is from the Enterprise.

\subsubsection{Lateral Coordination Between the Enterprise, Municipality and the City}

Article 8 of the Proclamation № 65/2003, a regional statute for establishing of urban local governments in Oromia, mentions water and sewerage service as part of the municipalities service provision in the region. But Proclamation No. 78/2004 for the establishment of urban water supply service enterprise separates the water supply service from the municipal services. Under the Proclamation $78 / 2004$ till the enactment of the amendment Proclamation $97 / 2005$, the urban water management was chaired by the Mayor. This was later changed and the selection of the chairperson of the water management Board is the mandate of the BoWERD of Oromia, not of the city. This has made the formal and structural connection between the urban water supply enterprise and the city administration. In the case of Adama, the Mayor is one of the members of the water management Board. But the legal framework does not oblige the Mayor to be a member of the water management Board. The chairperson of this Board is by the BoWERD.

The stories from the key informants showed that instead of supporting the capacity building of the Enterprise, the Municipality has been belittling the Enterprise in terms of decision making and financial contributions. On the financial side, the Enterprise state that the municipality has been reluctant to pay for the damages of the water pipelines caused by them. For example, in the year 2014/15, the Enterprise had incurred up to ETB 20 million due to the municipality's destruction of water pipelines. Subsequently, the Enterprise had planned to collect about ETB 20,607,750.71 from the 
Municipality but it was not credited [72]. Instead of forcing the municipality to pay for the destruction it has brought to water utility lines, the Enterprise manager started repairing the water lines using the enterprise's budget. On the decision making side, the manager of the Enterprise could not force the municipality to pay for the destructions it had brought to the water pipelines as the manager and the Mayor gloss over the issue with same party line accountability. In addition, the manager of the urban water enterprise's unofficial accountability to the Mayor of the city demonstrates the political significance of the managerial position than professional value. Nonetheless, the city administrator shows up its collaboration with Adama city water supply enterprise at times when the urban water crises affect the political support of the people to OPDO and ramifications of the water crises on governing the city and city's relation to the regional government.

\subsubsection{Relations Between the Enterprise and Electric Power Corporation (ELPCo)}

In the views of the service providers, the interruption of electrical power has hugely impacted the water supply system in the city of Adama. There was power interruption for about 196 hours in 2015 , and $160,720 \mathrm{~m}^{3}\left(196 * 820 \mathrm{~m}^{3}\right)$ water was not produced due the interruption. Nonetheless, the Enterprise has been paying huge money to Electric Power Corporation every year as part of its direct water production costs.

Table 5. Trends of Direct Water Production Costs.

\begin{tabular}{llllr}
\hline \multirow{2}{*}{ Fiscal Year } & \multicolumn{2}{l}{ Direct Production Costs } & \multicolumn{2}{c}{ Total } \\
\cline { 2 - 5 } & Electricity & Chemicals & Diesel & $8,091,235.00$ \\
\hline 2009 & $4,214,443.00$ & $3,769,758.00$ & $107,034.00$ & $9,686,543.00$ \\
2010 & $4,494,196.00$ & $5,095,593.00$ & $96,754.00$ & $11,413,494.00$ \\
2011 & $4,893,099.00$ & $6,504,546.00$ & $15,849.00$ & $16,967,846.43$ \\
2012 & $5,491,289.98$ & $10,986,570.03$ & $489,986.42$ & $13,881,958.41$ \\
2013 & $5,133,697.67$ & $8,660,018.00$ & $88,242.74$ & 36.39 \\
2014 & $12,231,194.21$ & $7,125,490.98$ & $135,410.68$ & 36.98 \\
2015 & $11,812,514.61$ & $3,946,866.04$ & $73,537.43$ & 62.75 \\
\hline
\end{tabular}

Source: Computed by Researcher from ACWSSE August 2016

From 2009 to 2015, averagely about $50 \%$ of the direct production costs were due to the payment made for electric power consumption. According to the expert explanation [73], the standard land use plan for utilities including water, telecommunication and electricity is $4 \mathrm{~m}$ wide. Because of the lack of coordination and integration of their activities, there have been problems of destruction of supply lines one by the other.

\section{Conclusion}

This study has examined decentralization and the functioning of urban local governments with reference to water-supply service delivery. The study found out that decentralized urban governance of Adama has not been effective in the delivery of water supply services. A number of factors have contributed to this situation of ineffective decentralization.

Firstly, Adama city lacks legal and institutional security which paved the way for a dependent political power relation between the city and the regional state of Oromia. This could also be interpreted as a means by which the political elites at the regional level control the city through political means from above.

Secondly, the power to determine the structure, human resources and funding of urban water-supply projects is granted to regional state government, whereas the responsibility to provide water-supply service is given to urban local government. Although the function of water-supply service delivery is located at the city level, it is the regional water bureau that has meaningful technical and financial capacities.

Indeed, it has been the Regional Water Bureau that determines the structure of the enterprise and undertakes capacity-building tasks; as for the enterprise, it cannot escape control by the Bureau, which often comes in the form of technical and financial support. Furthermore, the supreme organ of the urban water-supply enterprise - the management board - is established by the Water Bureau, to which it is accountable; the Bureau in turn is accountable to the regional cabinet, itself accountable to the regional state council. This not only creates a long accountability route but precludes the local city council from this same accountability route.

The logic of decentralization could have empowered the technical department of the local water-supply enterprise to carry out design upgrading, but the enterprise could not perform such functions because it lacks the mandate and capacity to do so. Instead, it relies on the expertise and material support of the Regional Water Bureau and beyond. Even worse, the revenue that the enterprise collect could not make the Enterprise design or redesign water projects because the internal revenue only covers recurrent expenditure and small operational and maintenance costs. It cannot cover additional water infrastructural expansion. Weak revenue-raising capacity is hence a barrier to a water supply-service that is more responsive to the changing nature of the demand for water supply. Thus, the evidence from the city of Adama shows that the enterprise cannot function autonomously because its capacity to deliver urban water 
service is undermined by the lack of the required human, material and financial resources at the local level.

Thirdly, decentralized urban governance has not led to effective urban water-service delivery compatible with the pace of urbanization of Adama. The city has been undergoing rapid but mostly informal urbanization. Consequently, the city's physical expansion has already gone beyond the pressure zones for the water supply distribution systemmeaning that water supply does not reach the municipal boundary.

Fourthly, through the establishment of urban water-supply service delivery in the form of the 'enterprise model' was meant to reduce the influence of politics on the management and delivery of water, politics has remained the key factor influencing water-supply services in the city of Adama. In fact, water problems cannot be addressed solely by the enterprise's manager and professionals but inevitably involve the power-holders or authorities who set priorities and allocate resources at national, regional and local levels. The problem, however, is the lack of clear boundary between those who control the implementation of their decisions and those who implement or engage in service provision. The exposition to this is that the Enterprise manager focuses on clientelist relation with the upper level Board and Bureau rather than with the local community. The hierarchical political culture along with the upward accountability of the Enterprise manager has reinforced the influence of political factors from above.

Finally, Ethiopia's urban water policy and institutional frameworks make multilevel institutional cooperation - along both the vertical and horizontal dimensions - a matter of necessity rather than choice in securing the provision of water supply services. However, such coordination arises only when there is a water crisis and it becomes politically expedient as a firefighting strategy. Barring the city's water supply enterprise unofficial political accountability to the mayor of the city, there is no structural and legal connection between mayor and the city's water enterprise. Instead, it is through the party channel or personal relationships that they are connected, given that both of them are affiliated to the same ruling party and are also members of the enterprise's management board, where they meet to make decisions about water-supply services. The municipality is, for example, expected to pay for any damage it causes to water pipelines, but this seldom happens, seeing as there are no formal rules that obligate the mayor to do so. This shows that there is a lack of clear lines of institutional communication between the water enterprise and the city administration; it also shows that the enterprise model of water-supply service is deficient in that it fails to anticipate the inevitability of institutional interconnection between the enterprise and the city.

In a nutshell, neither the decentralized urban governance nor the multilevel institutional coordination and stakeholder involvement is sufficient to deliver effective urban water-supply services. Therefore, this study argues that decentralization could resolve the problem of water-supply services if local governments are endowed with the capacity to match the functional responsibilities granted to them. The implication is that for the urban local government to deliver effective water-supply service, the decentralization process needs to ensure adequate local capacity and effective coordination and partnership between the multilevel water institutions and stakeholders.

\section{References}

[1] Rondinelli, D., Government decentralization in comparative perspective: Theory and practice in developing countries. International Review of Administrative Sciences, 47 (2), 133-45, 1981.

[2] Okafor, J., Local government financial autonomy in Nigeria: The state joint local government account. Commonwealth Journal of Local Governance, 6., 2010.

[3] Dafflon, B. and Madiès T., Decentralization: A Few Principles from the Theory of Fiscal Federalism Notes and Documents No. 42 University of Fribourg, Switzerland, 2009.

[4] Shah, S., Ahmed, J. \& Devarajan, S., Decentralization and service delivery (World Bank Policy Research Working Paper No. 3603). Retrieved from https://bit.ly/2E5pxCZ, 2005.

[5] Mulugeta, D., Decentralization in Ethiopia: Concept and process - the case of Dendi District, West Shoa Zone of Oromia State. Technische Universität Dortmund, Germany: $\mathrm{PhD}$ thesis, 2012.

[6] Kanea, K., Decentralized governance and service delivery: A case study of Digelu and Tiju woreda of Arsi Zone in Oromia Regional State. Addis Ababa, Ethiopia: PhD thesis, 2006.

[7] Grindle, M., Going local: Decentralization, Democratization and the Promise of Good Governance, Princeton: Princeton University Press, 2007.

[8] Cohen, J. M. \& Peterson, S. B., Administrative decentralization: Strategies for developing countries. Sterling: Kumarian Press, 1999.

[9] Oates, W., An essay on fiscal federalism. Journal of Economic Literature, 37, 1120-1149, 1999.

[10] Venugopal, V. and Yilmaz S., "Local Government Discretion and Accountability in Ethiopia", International Studies Program Working Paper 08-38, Andrew Young School of Policy Studies, Georgia State University, 2008.

[11] Beer-Tóth, K., Local financial autonomy in theory and practice: The impact of fiscal decentralization in Hungary. University of Fribourg, Switzerland: $\mathrm{PhD}$ thesis at pp. 80, 2009.

[12] Bird, R. M., Intergovernmental fiscal relations: Universal principles, local applications (International Studies Program, Working Paper No. 2.). Atlanta: Andrew Young School of Policy Studies, 2000.

[13] Shah, A., The Reform of Intergovernmental Fiscal Relations in Developing and Emerging Market Economies. Washington, DC: World Bank, 1994.

[14] Beer-Tóth, K., Local financial autonomy in theory and practice: The impact of fiscal decentralization in Hungary. University of Fribourg, Switzerland: PhD thesis, 2009. 
[15] Yilmaz, S., Beris Y. \& Serrano-Berthet, S., Local government discretion and accountability: A diagnostic framework for local governance, social development (The World Bank Working Paper No. 113), 2008. at 21.

[16] Rogers, P. \& Hall, A. Effective Water Governance. Technical Committee Background Paper No. 7. Global Water Partnership (GWP), Stockholm, 2003, in Plummer, J \& Slaymaker, T. Rethinking governance in water services, Working Paper 284, Overseas Development Institute, 2007 at pp. 4.

[17] United Nations Development Program, Governance for Sustainable Human Development, Policy Document, 1997.

[18] Plummer, J. \& Slaymaker, T., 'Rethinking Governance in Water Services', Overseas Development Institute, SE7 1JD London, 2007.

[19] Heller, L., Different approaches in Analyzing Urban Governance implications to Belo Horizonte, Brazil, the First SWITCH Scentific Meeting, University of Birmingham, UK, 2007.

[20] Rees, J. S., 'Urban water and Sanitation Services, IWRM Approach', Global Water Partnership, No. 11. Elnders Ab, Sweden, 2006 at pp. 9.

[21] Bahri, A, Integrated Urban Water Management, Global Water Partnership Technical Committee (TEC), Background Papers No. 16, 2012.

[22] Alba, R., 'Featuring Urban Water Supply Governance: An Overview', Water Power Working Paper, No. 4, Governance and Sustainability Lababoratory Trier University, Trier, 2016.

[23] Article 39 (3) and 88 (1) of the FDRE Constitution

[24] Article 50 (4) of the FDRE Constitution.

[25] Article 51 (2), FDRE Constitution (1995).

[26] Birhanu, K \& Gebreegziabher, T 'A Literature review of Decentralization in Ethiopia', in Taye Assefa Tegegne Gebre-Egziabher, Decentralization in Ethiopia Forum for Social Studies, 2006

[27] Ayele, Z. \& Fessha, Y. (2012). The constitutional status of local government in federal systems: The case of Ethiopia. Indiana University Press, Vol. 58, No. 4, Pp 88-109.

[28] Article 88 (1), FDRE Constitution (1995).

[29] Ministry of Works and Urban Development (2007), Plan for Urban Development and Urban Good Governance, Plan for Accelerating Sustainable Development to End Poverty -PASDEP (2005/06-2009/10).

[30] United Nations Human Settlements Programme (UN Habitat), Ethiopia Urban Profile, regional and technical cooperative division, 2008.

[31] Municipal Decentralization Study, 2001.

[32] Ayele, Z. \& Fessha, Y., The constitutional status of local government in federal systems: The case of Ethiopia. Indiana University Press, Vol. 58, No. 4, Pp 88-109, 2012.

[33] Venugopal, V. \& Yilmaz S. Local government discretion and accountability in Ethiopia (International Studies Program Working Paper 08-38). Georgia State University: Andrew Young School of Policy Studies, 2008.
[34] Di Nunzio, M., What is the Alternative? Youth, Entrepreneurship and the Developmental State in Urban Ethiopi, Development and Change 46 (5): 1179-1200, 2015.

[35] Dorosh, P. \& Schmidt, E., 'The rural-urban transformation in Ethiopia', IFPRI Ethiopia Strategy Support program 2 Working Paper No. 13 and World Bank, Ethiopia Poverty Assessment, Chapter VII, Draft, 2010.

[36] Article 10 of Proclamation No 65/2003 for establishment of Urban Local Governments of Oromia, Megeleta Oromia, Finfine, $22^{\text {nd }}$ June.

[37] Article 7 of Proclamation No. 116/2006 for amending the of Proclamation No. 65/2003 for establishment of Urban Local Governments of Oromia, Megeleta Oromia, Finfine, $12^{\text {th }}$ July.

[38] Birhanu, M., 'the City of Addis Ababa: Policy Options for Governance and Management of a city with Multiple Identity', Forum for Social Studies Paper No-2 Addis Ababa, 1998.

[39] National Civic League, Model City Charter, $8^{\text {th }}$ edition, Denver, 2003.

[40] Interview: ex-Municipal Manager, August 2017.

[41] Articles 51 (5) and 52 (2) (c) of the FDRE Constitution.

[42] Kabiso, K., Urban Water Supply in Hossana Town of Hadiya Zone, SNNPR. MA Thesis, Haramaya University, Ethiopia, 2015.

[43] Water Resources Management Policy (WRMP), 1999.

[44] Arsano, Y., Mekonnen, E., Gudisa, M. \& Achiso, D., Governance and Drivers of Change in Ethiopia's Water Supply Sectorstudy conducted by the Organisation for Social Science Research in Eastern and Southern Africa (OSSREA) in collaboration with the Overseas Development Institute (ODI) at pp. 12, 2010.

[45] Article 8 (1) of the Proclamation No 78/2004.

[46] Article 8 (3a-f) and 14 (2) of the Proclamation No 78/2004.

[47] Article 2 (2b) Proclamation No 97/2005 to amend Proclamation No 78/2004 to provide for the Establishment of Urban Water Supply and Sewerage Service Enterprise of ONRS, Megeleta Oromia, Finfine

[48] Interview: Senior Engineer, August, 2018, Adama

[49] Article 8 (3f) and Article 11 (1) of Proclamation No 78/2004.

[50] Article 11 (2 (c, g and i) of Proclamation No 78/2004 to provide for the Establishment of Urban Water Supply and Sewerage Service Enterprise of ONRS, Megeleta Oromia, Finfine.

[51] Mebratu, A, 'Spontaneous Development of Urban Centers, An Analysis of the Transformation Process of Adama and its Primary Commercial Centers', PhD Thesis in Architecture and Urban Planning, Addis Ababa University, 2006.

[52] Emana, G, 'the History of Adama', MA Thesis, Department of History, Addis Ababa University, 1996.

[53] Adama City Water Supply Service Enterprise Work Plan 2016.

[54] Baryou, A, 'Analyses of Affordability and Determinants of Willingness to Pay for Improved Water Service in Urban Areas, Strategy for Cost Recovery: Case Study of Nazareth Town', Msc Thesis, Economic, Addis Ababa University, 2002. 
[55] Report: Optimization/Upgrading on Adama Water Supply System, 2012, Oromia.

[56] Interview: Head of the Technical Unit, December 2018

[57] Interview: Senior Hydraulic engineer, August, 2018.

[58] Interview: Head of the Technical Unit of ACWSSE, December, 2018.

[59] Article 20 (a) of Proclamation No 78/2004. to provide for the Establishment of Urban Water Supply and Sewerage Service Enterprise of ONRS, Megeleta Oromia, Finfine.

[60] Article 20 (2a-e) of Proclamation No 78/2004 to provide for the Establishment of Urban Water Supply and Sewerage Service Enterprise of ONRS, Megeleta Oromia, Finfine.

[61] Article 20 of Proclamation No. 78/2004 to provide for the Establishment of Urban Water Supply and Sewerage Service Enterprise of ONRS, Megeleta Oromia, Finfine.

[62] Informal Interview: Anonymous, Ganda Dhaka Adi,, April 2017.

[63] Report on Adama Water Supply System Optimization/Upgrading, 2012, Oromia.
[64] Interview: Senior Hydrologist, ACWSSE, April 2017.

[65] Interview: Head, Technical unit of ACWSSE, December 2018.

[66] Report: Adama Water Supply Optimization system, 2015.

[67] Article 23/2 of the Proclamation No 78/2004 to provide for the Establishment of Urban Water Supply and Sewerage Service Enterprise of ONRS, Megeleta Oromia, Finfine.

[68] Article 14 (2) of the Proclamation No 78/2004 to provide for the Establishment of Urban Water Supply and Sewerage Service Enterprise of ONRS, Megeleta Oromia, Finfine.

[69] ORTO: Mr. Assefa, Head of the BoWERD, December 2016.

[70] Interview: Senior Engineer, Adama City, August, 2018

[71] Interview: Auditor, ACWSSE, August 2017.

[72] ACWSSE Performance Report 2016

[73] Interview: Senior Hydraulic Engineer, ACWSSE August 2018, Adama. 